\title{
Constraints to extension service delivery in the production, processing and marketing of gum arabic in magumeri local government area of Borno State, Nigeria
}

\author{
${ }^{1}$ Gwary, M. M., ${ }^{2}$ Donye, A. O., ${ }^{3}$ Wakawa, R. C. and ${ }^{1}$ Shallangwa, M. D. \\ ${ }^{1}$ Department of Agricultural Extension Services, University of Maiduguri \\ ${ }^{2}$ Department of Agricultural Economics and Extension, Adamawa State University, Mubi \\ ${ }^{3}$ Ramat Polytechnic, Maiduguri
}

\begin{abstract}
This study determined the constraints limiting extension's role in the production, processing and marketing of Gun Arabic in Magumeri Local Government Area of Borno State, Nigeria. Both primary and secondary data were used for the study. The primary data include structured questionnaires administered to 75 randomly selected farmers involved in the marketing and processing of Gum Arabic in the study area. The findings of the study revealed that majority $(71 \%)$ of the farmers are married, most (33\%) of them indicated income derived from Gum Arabic business between $\mathrm{N} 100,000-\mathrm{N} 200,000$. Family sizes of the respondents are mainly between 6-10 persons (39\%). Among the income level variables, $\mathrm{N} 100,000$ (calculated $\mathrm{X}^{2}=0.13$; Tabulated $X^{2}=3.841$ ), N200, 000 (calculated $X^{2}=0.0928 ;$ Tabulated $X^{2}=3.841$ ), N201, 000 (calculated $X^{2}=0.2207$; Tabulated $X^{2}=3.841$ ), and $\mathrm{N} 500,000$ (calculated $X^{2}=0.147$; Tabulated $X^{2}=0.841$ ) were found to be not significantly related to access to extension at $5 \%$ level of significance. Results of the correlation analysis revealed that there are both positive and negative relationships between access to extension and the socio-economic variables: Farm size $(r=0.804)$; Educational level $(r=0.829$; Age $(r=-0.362$ and family size $(r=-0.150)$ with all the values significant at 0.05 level. Accessibility to adequate capital (40\%), loss due to spoilage $(30 \%)$, storage (35\%) and transportation (45\%) were the major problems cited by the respondents as constraints to their involvement in marketing and processing of Gum Arabic. Based on the results, there is a need to enhance farmers' access to appropriate and effective extension services and training in agro-forestry; encourage establishment of Gum Arabic plantations and identification of more marketing outlets and provision of credit facilities to farmers.
\end{abstract}

Key words: Constraints; Extension Service Delivery; Production; Processing; Marketing; Gum Arabic.

\section{INTRODUCTION}

Gum Arabic is an ancient ingredient used as a binder in cosmetics and inks and as an agent of mummification process since $4000 \mathrm{BC}$. Its use thus dates back almost 6000 years to the time of the ancient Egyptians. It is the oldest and best known of all the natural gums. The name Gum Arabic was used in describing the commodity because it was then shipped through Arabian ports to Europe and other distribution centres.

Gum Arabic is the dry exudes obtained from the stems and branches of Acacia Senegal (L) or closely related species. It is a natural gum harvested from the exterior of acacia trees in terms of dry hard nodule up to $50 \mathrm{~mm}$ in diameter and ranges from almost colourless to brown. Although most internationally traded Gum Arabic comes from Acacia Senegal, the term Gum Arabic or Gum Acacia cannot be taken as implying a particular botanical source. In some cases, the so-called Gum Arabic may not even have been collected from Combretum Albezia or other Genera (FAO, 1996; Bababe, 2002).

The gum from Acacia Senegal is an important source of income in Sudan, Nigeria, Chad and Senegal. Sudan is the leading producer of Gum Arabic where $85 \%$ of the total world's supply of gum is produced (Wickens et al. 1984). Nigeria is said to be the third major producer of the commodity after Sudan and Chad accounting for $20 \%$ of global production (About 9000 metric tonnes of Gum Arabic per annum) (Bababe, 2002). According to Sanusi, et al. 2002) the 
desert frontline line states in Nigeria comprising of Borno, Bauchi, Jigawa, Katsina, Kebbi, Sokoto and Yobe states are the major Gum Arabic producing areas in the country.

Gum Arabic is also used extensively in the local economy. The first grade Gum Arabic finds use in confectionaries and pharmaceutical industries, while the second grade finds use in other industrial applications. However, processed Gum Arabic is useful in local industries. The local price for the produce varies from season to season and from growing state to another. Market prices have been fluctuating locally mainly due to increases in export prices associated with the devaluation of the Nigerian currency (Naira).

The general role played by extension is to disseminate information, provide assistance and advice to farmers in order to increase their cleaning and quality control procedures. Extension workers provide comprehensive information in the areas of processing, marketing and research and development among others so as to encourage prospective investors venture into the processing of Gum Arabic. They are equally involved in boosting the supply of Gum Arabic as agricultural raw materials for industrial use. The local market system for Gum Arabic in the unprocessed form is quite limited with most of the commodity being exported. The collectors sell their gum at regular gum auctions, usually to traders who then sell it to the Gum Arabic Company. Advice on market outlets and value addition also constitutes responsibility of the extension agency.

Research on Gum Arabic especially with respect to extension service activities in Nigeria are limited and do not seem to have been given the desired attention. Most of the farmers contact fellow farmers and other individuals when they face problems in the cultivation of the plant, while few of them contact Agricultural Centres. Farmers are therefore, faced with the problems of inadequate facilities and knowledge about the processing of Gum Arabic, effects of pests and diseases, inadequate finance, deforestation through bush burning and land tenure system relating to Gum Arabic production.

In view of above, the main objective of the study was to analyze the role of extension in the processing and marketing of Gum Arabic in Magumeri Local Government of Borno State. The specific objectives were to: identify the socio-economic characteristics of the respondents involved in the processing and marketing of Gum Arabic; assess the extension services rendered to the respondents in the processing and marketing of Gum Arabic; determine the problems encountered by the respondents in the processing and marketing of Gum Arabic and, identify the constraints limiting extension service delivery in the processing and marketing of Gum Arabic in the study area;

In order to achieve the objectives of the study the following hypotheses were tested.

1. There is no significant relationship between the socio-economic characteristics of the respondents and access to extension services.

2. There is no significant relationship between the level of income of the respondents and access to extension services in the processing and marketing of Gum Arabic.

\section{METHODOLOGY}

The Study Area: The area of the study is Magumeri Local Government Area which is one of the 27 Local Government Areas in Borno State. It is located between latitude $11^{\circ}, 50^{\prime \prime} \mathrm{N}$ to $12^{\circ}, 35^{\prime \prime} \mathrm{N}$ and longitude $11^{\circ}, 10^{\prime \prime} \mathrm{E}$. According to the 2006 census the study area has a population of 140,231 (NPC, 2006).

Sampling Procedure: The target population for the study is Gum Arabic producers in Magumeri Local Government Area. There are thirteen political wards in the local government area. Purposive and simple random sampling procedures were employed in the selection of the wards and respondents for the study. The purposive sampling technique was used in the selection of five (5) wards where Gum Arabic farmers were found. Fifteen (15) respondents were randomly selected from each of the wards, bringing the total number of respondents to seventy five (75) to whom structured questionnaires were administered.

Techniques for Data Analysis: Descriptive and inferential statistics were employed for the analysis of the data obtained. The socio-economic characteristics of the respondents were analyzed using descriptive statistics such as frequencies and percentages. The hypotheses tested were analyzed using inferential statistics such as correlation and chisquare. The chi-square model used was as follows:

$X^{2}=\sum \frac{(O-E)^{2}}{E}$ 
Where: $\mathrm{X}^{2}=$ computed chi-square $\quad \mathrm{E}=$ expected frequency

$$
\mathrm{O}=\text { observed frequency } \quad \Sigma=\text { summation }
$$

Correlation analysis was undertaken using statistical Package for the Social Sciences (SPSS) computer software and the result generated interpreted accordingly.

\section{RESULTS AND DISCUSSION}

Table 1 shows the distribution of the respondents according to their socio-economic characteristics. The results indicate that majority $(40 \%)$ of the respondents were within the age range of $31-40$ years. This shows that most of them are within the economically active age range. They are strong and agile enough to endure hard working conditions. This implies that they constitute a strong force in the Gum Arabic business of marketing of the commodity. Most of the respondents (34.6\%) did attend various tertiary institutions, which means that they have the required Table 1: Socio-economic Characteristics of Respondents_(N=75).

\begin{tabular}{lcc}
\hline $\begin{array}{l}\text { Variable } \\
\text { Age (years) }\end{array}$ & Frequency & Percentage \\
\hline $31-40$ & 29 & 32.2 \\
$41-50$ & 18 & 20.0 \\
51 and above & 10 & 11.1 \\
Marital Status & 04 & 05.6 \\
Single & 71 & 94.4 \\
Married & & \\
Family size & 15 & 20 \\
$1-5$ & 39 & 52 \\
6-10 & 21 & 28 \\
Above 10 & & 33.3 \\
Educational Level & 25 & 33.3 \\
Qur'anic education & 40 & 21.1 \\
Primary education & 30 & 44 \\
Secondary education & 19 & 33.3 \\
Tertiary education & & 22.6 \\
Income & 33 & 40 \\
N100, 000-200, 000 & 25 & 28 \\
N201, 000-500, 000 & 17 & 14.6 \\
Above N500, 000 & & 17.3 \\
Primary occupation & 30 & 34,6 \\
Farming & 21 & 32.1 \\
Crafting & 11 & 33.3 \\
Civil service & 13 & \\
Business & & \\
Secondary occupation & 26 & 24 \\
Marketing & 25 & \\
Civil service & & \\
Farming & & \\
\hline Source: Feld Survey, & 212 & \\
\hline
\end{tabular}

levels of education that enable them to easily understand and adopt new agricultural technologies. The education could also facilitate efficient performance in terms of the processing and marketing of Gum Arabic.

The table also shows that $44 \%$ of the respondents earn between $\mathrm{N} 100,000-\mathrm{N} 200$, 000, while 33.3\% and $22.6 \%$ earn between N201, 000 - N500, 000 and above $\mathrm{N} 500,000$ possible because of the high levels of education attained by the respondents. The local price of Gum Arabic varies from season to season with higher prices recorded during the off-season period, while lower prices occur during the on-season period. Interview with respondents indicated that offseason price of $\mathrm{N} 270,000$ and $\mathrm{N} 230,000$ per metric tonne respectively were recorded in Kano and Borno states during the previous year (2007).

Source: Field Survey, 2012 


\section{Constraints to Gum Arabic Production,} Processing and Marketing

Table 2 presents constraints being encountered by gum Arabic producers in terms of production activities, processing and marketing. Lack of capital/lack of access to loans or financial assistance was indicated by most (46.66\%) of the respondents as a serious problem militating against their Gum Arabic production, processing and marketing. Losses due to spoilage were reported by $26.66 \%$ of them to be a constraint. Other constraints reported includes,

inadequate marketing and processing facilities $(6.66 \%)$, inadequate sales $(13.3 \%)$ and transportation $(2.66 \%)$ According to a study by Folorunso et al. (2002) most of government activities on Gum Arabic in Nigeria has been limited to production. The marketing of the produce has virtually been ignored except on the aspect of price ceiling. There is no marketing board for the commodity. As a result individuals and private companies are involved in the marketing business. Transportation and storage cost as well as losses due to spoilage constituted the main causes of high cost of production.

Table 2: Constraints to Gum Arabic Production, Processing and Marketing

\begin{tabular}{|c|c|c|c|}
\hline Constraints & Frequency & Percentage & Rank \\
\hline Accessibility to capital & 35 & 46.66 & 1 \\
\hline Loss due to spoilage & 20 & 26.66 & 2 \\
\hline Inadequate processing and marketing facilities & 05 & 06.66 & 3 \\
\hline Inadequate sales & 10 & 13.33 & 4 \\
\hline Storage & 03 & 04.00 & 5 \\
\hline Transportation & 02 & 02.66 & 6 \\
\hline
\end{tabular}

Source: Field Survey, 2012.

Constraints Limiting Extension Services Provided to Respondents: Table 3 shows the type constraints that limit the delivery of extension services to the respondents. Untimely/lack of or inadequate supply of essential inputs were indicated by $40 \%$ of the respondents as a major factor that hinders the delivery of extension services to them. Lack of commitment on the part of available field agents was opined by $13.3 \%$ of the respondents to be responsible for limited extension services delivery in the study area. The constraint of lack of evaluation techniques by extension agents and inadequate supervision cited as problems by $6.66 \%$ respectively. The result shows that there are challenges limiting effective delivery of extension services to the respondents and this underlies the need for deliberate efforts to improve the performance of extension workers and range of extension activities aimed at promoting not only production but processing and marketing of gum Arabic in the study area.

Table 3: Constraints Limiting Delivery of Extension Services Provided to Respondents

\begin{tabular}{llcc}
\hline Constraints & Frequency & Percentage & Rank \\
\hline Untimely supply/lack of essential inputs & 30 & 04.00 & 1 \\
Lack of commitment of extension agents & 10 & 13.30 & 2 \\
Extension agents attitude & 20 & 20.60 & 3 \\
Lack of effective communication & 05 & 06.66 & 4 \\
Inadequate supervision by extension agents & 05 & 06.66 & 5 \\
Lack of evaluation techniques by extension agents & 05 & 06.66 & 7 \\
\hline
\end{tabular}

Source: Field Survey, 2012.

Correlation Analysis between Socio-Economic
Characteristics of Respondents and Access to Extension Services: The result of correlation analysis presented in Table 4 indicated that there is a negative and significant relationship $(r=-0.362)$ between age of the respondents and access to extension services. This implies that as respondents grow older, they tend to have less access to extension services. This could probably be as a result of their belief that they have acquired much experience in the marketing and processing of Gum Arabic. There was a high correlation $(r=0.328)$ between access to extension services and level of education of the respondents. This means that the higher the level of education of the respondents the more their access to extension services. This is probably because of their ability to read, understand and apply the recommended improved practices. 
Access and farm size were found to have a positive and significant relationship $(r=0.805)$. This implies that the larger the farm sizes the more the access of the respondents to extension services. This could have been necessitated by the desire of the

Table 4: Result of Correlation Analysis between Socio-economic Characteristics of Respondents and Access to Extension

\begin{tabular}{lcl}
\hline Variable & Correlation Coefficient & Remark \\
\hline Age & $-0.362^{* *}$ & $\mathrm{~S}$ \\
Educational level & $0.829^{* *}$ & $\mathrm{~S}$ \\
Marital status & -0.221 & $\mathrm{NS}$ \\
Farm size & $0.805^{\star *}$ & $\mathrm{~S}$ \\
Family size & $-\mathbf{0 . 1 5 0}$ & $\mathrm{S}$ \\
\hline
\end{tabular}

Source: Field Survey, 2012.

${ }^{* *}$ Significant at $0.05 \%$ level

*Significant at $0.01 \%$ level

$\mathrm{S}=$ Significant

NS=Not Significant

Chi-Square Analysis of Access to Extension Services and the Level of Income of the Respondents: Table 5 presents the summary of the chi-square test between access to extension services and the level of income of the respondents. The results reveal that the tabulated $X^{2}$ value at $0.05 \%$ level of significance was $=3.841$. Since the computed $X^{2}$ value is less than the tabulated ${ }^{2}$ value,

Table 5: Summary of the Chi-Square Analysis respondents to look for much agricultural information in order to ensure that no loses are incurred since much money must have been spent or invested on large farms. then we accept the null hypothesis and hence, conclude that there is no significant relationship between access to extension services and the level of income of the respondents in the processing and marketing of Gum Arabic in the study area. This implies that whether or not the respondents have access to extension services or not, it does not affect their level of income.

\begin{tabular}{|c|c|c|c|c|}
\hline $\begin{array}{l}\text { Variable } \\
\text { Access to extension }\end{array}$ & Calculated_X $\mathrm{X}^{2}$ & DF_ & _Tabulated_ $X^{2}$ & Remark \\
\hline \multicolumn{5}{|l|}{ At least } \\
\hline Once a year & 0.1391 & 1 & 3.841 & NS \\
\hline None & 0.2207 & 1 & 3.841 & NS \\
\hline \multicolumn{5}{|l|}{ Income level } \\
\hline $\mathrm{N} 100,000.00$ & 0.1391 & 1 & 3.841 & NS \\
\hline $\mathrm{N} 200,000.00$ & 0.9280 & 1 & 3.841 & NS \\
\hline N300, 000.00 & 0.2207 & 1 & 3.841 & NS \\
\hline N500, 000.00 & 0.1471 & 1 & 3.841 & NS \\
\hline
\end{tabular}

Source: Field Survey, 2012.

DF $=$ Degree of Freedom

NS $=$ Not Significant

\section{CONCLUSION}

Farmers play a significant role in Gum Arabic production, processing and marketing in Nigeria and the study area is among the major areas of cultivation of the crop in the country. It is apparent from the results that lack of effective and efficient extension services to the farmers is a key constraint limiting the processing and marketing of the commodity which is also referred to as 'desert gold'. The study identified 
size of the respondents as well as their educational level. It can be concluded that Borno state have the potential to be a centre for gum Arabic production in Nigeria, especially if the challenges facing the farmers as identified in the study are removed.

\section{RECOMMENDATIONS}

Based on the findings of the study, the following recommendations were made:

1. Farmers involved in the production, processing and marketing of Gum Arabic should be trained in innovative methods of these activities by the Borno State Government, and particularly by the Borno State Agricultural Development Programme (BOSADP).

2. Extension workers should intensify delivery of extension services to Gum Arabic farmers and also ensure that they pay regular visits and assistance. They should guide and lead farmers to relevant marketing centres as well as advising them on how to form cooperative societies in order to access loans from government and other agriculture related agencies and non-governmental bodies.

3. It was suggested that to improve marketing of Gum Arabic in the study area, there is a need to establish appropriate industries that can utilise the product and the identification of more export marketing outlets.

4. In order to make Gum Arabic production sustainable and economically viable more incentives should be given to people to establish Gum Arabic plantations and farmers provided extension services in the area of agro-forestry to incorporate acacia trees into their cropping system.

\section{REFERENCES}

Bababe, B. (2002). Preview of the Roving Training Workshop for Gum Arabic farmers. In Bababe and Ezinma (eds) Gum Arabic Tapping Techniques. Roving Training Workshop Modules for Gum Arabic Farmers. A Roving Training Workshop, Centre for Arid Zone Studies, University of Maiduguri, $24^{\text {th }}$ July- $4^{\text {th }}$ August, 2002. Pp.3-7.

Folorunso, R.O., R.O Kolo and B.G. Kolo (2002). Marketing of Commercial Gum Arabic. In Bababe and Ezinma (eds) Gum Arabic Tapping Techniques. Roving Training Workshop Modules for Gum Arabic Farmers. A Roving Training Workshop, Centre for Arid Zone Studies, University of Maiduguri, $24^{\text {th }}$ July- $4^{\text {th }}$ August, 2002. Pp.23-27.

Food and Agriculture Organization (FAO), (1996). Energy Sustainable Development and

Food Security in Africa. United Nations Conference on Environment and Development, Rome.

National Population Commission (NPC), (2006). Analytical Report of National Level. Omnia Press, Lagos.

Sanusi, S.S., Gwary, D.M. and Kabura, B.H. (2002). Identification of Gum Producing plants in the Nothern States of Nigeria. In Bababe and Ezinma (eds) Gum Arabic Tapping Techniques. Roving Training Workshop Modules for Gum Arabic Farmers. A Roving Training Workshop, Centre for Arid Zone Studies, University of Maiduguri, $24^{\text {th }}$ July- $4^{\text {th }}$ August, 2002. Pp.8-10.

Wickens,G.E., Goodin, J.R and Field, D.V. (1984) (Eds). Plants for Arid Lands. Proceedings of the Kew International Conference of Economic Plants for Arid Lands held at the Jodrell Laboratory, Royal Botanic Gardens, New England. George Allen and unwind, London, 23-27 $7^{\text {th }}$ July 1984. 